\title{
Effectiveness of Policy Implementation in Achievements of The Expected Food Pattern Score (Study in Kutai Kartanegara Regency, East Kalimantan)
}

\author{
Kus Indarto ${ }^{a} *$ \\ ${ }^{a}$ Universitas Mulawarman, Samarinda, East Kalimantan, Indonesia
}

\section{ARTICLE INFORMATION ABSTRACT}

\section{Article history:}

Data submission : 10 October 2019

$1^{\text {st }}$ revision: 10 November 2020

Accepted: 16 December 2020

Available online: 30 December 2020

Keywords: Public Policy Instruments, Implementation, Prostitution

\begin{abstract}
The purpose of this study is to analyze the effectiveness of achievement policy implementation of Expectation Food Pattern Score in Kutai Kartanegara Regency. This research is a qualitative inquiry, and using descriptive method. The novelty of this study is analyzed expectation food pattern score for whole community, while previous studies analyzed children age 2-6 years. The data collected were analyzed using Interactive Model Analysis by Miles, Huberman and Saldana. The findings in the field show that the implementation of achievement policy implementation of Expectation Food Pattern Score in Kutai Kartanegara Regency has met the criteria of 5 right, namely: right policy, right implementer/actor, right target, right environment, and right proses. In other word, the implementation has been effective.
\end{abstract}

2020 FIA UB. All rights reserved.

\section{Introduction}

Human need food to support their activity normally and productively. Most of Indonesia population eat is rice. For this reason, it is necessary to diversify food, so the food becomes nutritious, healthy and balanced. According Elizabeth (2011), food diversification is not intending to replace rice in full, but to improve people's food consumption pattern to become more diverse dan more nutritious.

The pattern of food consumption directing the food utilization pattern meet the principles of quality, variety, nutrition, safety and lawful. The food consumption pattern also aims to make the food utilization in body is optimal. In the household, the food consumption pattern is influenced by local economic, social and cultural conditions. For this reason, it is necessary to instill awareness about healthy food consumption pattern, both through formal and non-formal education. Expectation food pattern score is diverse food arrangement based on energy contribution from major food group, both in absolute terms and from food availability or food consumption (Technical Guideline for Minister of Agriculture Regulation No. 65 of 2010).
The Government of Kutai Kartanegara Regency has made efforts to improve the pattern of community food consumption, based on the Minister of Agriculture Regulation No.65 of 2010. In the regulation, one of indicator is the effort to achieve expected food pattern score. This study aims to analyze the effectiveness of the achievement policy implementation of expectation food pattern score. Therefore, determined the problem formulation in this study is: "How is the effectiveness of Achievement Policy Implementation of Expectation Food Pattern Score in Kutai Kartanegara Regency, East Kalimantan?

\section{Theory}

Public policy according Nakamura and Small (1980) as quoted by Wahab (2008:51) is "a series of policy maker's instruction to policy implementer that explain the goals and ways to achieve the goals. According Chocran and Malone (1995:1-2) public policy consists of political decisions to implement programs to achieve social goals. Parson (2008:113) said that in a democracy, public policy is a function of public opinion. Meanwhile, public opinion in politic is similar to consumer demand 
in the economic market. Policy request determine the policy offer. The policy agenda is strongly influenced by public opinion and public power. Opinion is measured dan treated with full attention by policy maker.

Thus, public policy is a policy maker's instruction to policy implementer, contains about social goals and how to achieve these goals. And public policy is function of publik opinion.

Policy implementation according Edward III (1980) as quoted by Dwidjowijoto (2006:140-141) is a way for a policy to achieve its goals. No more and no less. Wahab (2014:125) said that policy implementation involves complex rational and emotional processes. And study on public policy implementation will enter to the conflict area, complicated decisions, who gets what and how much.

According Nugroho (2014:686-690) there are 5 "right" to determine an effective policy implementation or not. Right policy. Does the policy include matters that will be solved; whether the policy has been formulated according the character of the problem to be solved; whether the policy was made by an institution that has the authority in accordance with the policy character; 2 . Right implementer/actor. In implementing the policy, the actor not only the governments, but cooperation between the government and the public/private sector, or implementation of privatized policies (contracting out/privatization); Right on target. Do the interventions targets as planned, do not overlap or conflict with other policy interventions; whether the target is ready to be intervened or not (whether in a conflict condition or not, whether in a condition of refusing or supporting); whether the policy implementation intervention is new or repeat the previous policy); Right environment. There are two environments. The first is policy environment, is the interaction between policy makers and policy implementers with other relevant institutions. The second environment is the external environment, is the public perception of policy implementation. It deals with perception from the mass media, pressure group, and individuals; Right process. The implementation of public policy consists of three processes, namely: Policy acceptance, in this process the public understand a "play" rule that is needed for the future, while the government understands it as a task to be carried out; Policy adoption, similar with policy acceptance; Strategic readiness. In this process, the public ready to implement or become part of the policy, and the implementing bureaucrats are ready to become implementers of the policy.

\section{Research Method}

This is a qualitative inquiry, using descriptive methods. Data was collected through interview observation and documentation. Interviews were conducted with the Head of Food Security and Counseling Agency of Kutai Kartanegara Regency, some official in the office, and some citizens. Interview using guidelines interviews to make collecting data easier. Guidelines interview make researcher fokus to get data needed observations were made by observing the food menu consumed by some Kutai Kartanegara Regency residents.

Data were collected from documents relating to efforts to achieve the expectation food pattern score. The document for example, Annual Report on Minimum Service Standard for Food Security and the data from Central Statistical Agency of East Kalimantan Province. The obtain data analyzed using an Interactive Model Analysis by Miles, Huberman and Saldana (2014). The study was conducted in Kutai Kartanegara Regency, East Kalimantan, Indonesia.

\section{Results}

The efforts made by the Government of Kutai Kartanegara Regency to achieve the expected food pattern score is accelerating the diversification of food consumption. Therefore, they do optimalization of the using yard. Diversification of food consumption based on local food sources. Then they develop sutainable food house area. The purpose of optimizing the use of yard are:

a. Increasing awareness, role and participation public in realizing diverse, nutritious, balanced and safe food pattern; and reducing dependence on rice;

b. Increasing woman farmer group participation to supply of food dan family nutrition through optimizing the use of the yard as a source of carbohydrate, protein, mineral and vitamins;

c. Encourage the development of micro-small and medium scale food management business as carbohydrates source, in addition to rice and flour based on resouces and local wisdom.

Meanwhile, the development of sustainable food house area is carried out by:

a. Establish Farmer Women Group, consists of 21 group from 18 villages; in 18 district;

b. Socializing optimization the using of the yard to 21 Farmer Women Group, followed by 378 member of Farmer Women Group;

c. Providing optimization package for each group, consist of vegetables seeds, polybags, organic pesticides, liquid organic fertilizer and manure.

Based on the research result in the field, the score of expectation food pattern has exceeded the specified target. The target is $90 \%$, and the achievement is $91.3 \%$ (Food Security and Counseling Agency, 2016). Thus, it can be said that the achievement policy implementation of Expectation food pattern score in Kutai Kartanegara Regency has been effective.

By looking at the results of achievement in the field, then the effectiveness or the implementation is analyzed using 5 "right" proposed by Nugroho.

Right policy. The existing policy, namely Regulation of the Agriculture Minister No.65 of 2010 have included about efforts to achieve expectation food pattern score; the policy has also been formulated with the character of 
the problems which will be solved; the existing policy made by institution which have authority in accordance with the character policy that has been made. The policy was made by the Minister of Agriculture.

Right implementer/actor. In implementing policy to achieve expected food pattern score, the main actor or implementer is the local government (Kutai Kartanegara Local Government). However, community are also involved, for example through the using og yard to be planted with plant which produce carbohydrates, proteins, minerals and vitamin. Actually, the private sector will already be involved in the program. Private sector will provide plant seeds, fertilizers and planting media. But because of the final crisis in the existing private companies, the plan cannot yet be implemented.

Right target. The target is in accordance with the plan, namely the whole community of Kutai Kartanegara Regency. The community also ready to be intervened, in the sense that they are not in a conflict. The community support for the policy.

Right environment. Interaction between policy makers dan policy implementers as well as other institutions involved in the implementation of the policy went well. Inside is coordination and communication. The public perception of the policy to achieve the expected food pattern score is good.

Right process. Policy acceptance. The government, in this case the Food Security and Counseling Agency, provide information about the importance of the expectation food pattern score and what plans will be implemented. Thus community knows about their role in the programs which will be implemented. Meanwhile, government also understands their duties in the efforts to realize expected food pattern score in Kutai Kartanegara Regency; Policy adoption. The community knows their role and the government understands their task to achieve expected food pattern score; Strategic readiness. The community is ready to carry out their role and the government is ready to be executor or guide of the community in implementing the program to achieve the expected food pattern score.

Effectiveness is related to the results achieved with the expected results. In other words, effectiveness is the relationship between output and goals. The greater the contribution output to the goal, the organization, program or activity is more effective. Economics focuses on input, efficiency focuses on outputs or processes, effectiveness focuses on outcomes. An effective program is a program which produces output that meets the expected goals (spending wisely) (Mahmudi, 2015:86). Associated this research, the goal of achieving the expected food pattern score is to achieve quality, diverse, nutritious, safe and lawful food.

Research conducted by Phulkerd, et. al (2017) said that in the implementation of policy to reduce unhealthy food advertisement on radio and television, there are several obstacles, namely: lack of monitoring and evaluation systems monitoring, lack of organizational knowledge regarding the skill needed in implementing policy, poor governance system, lack of fund and resources, lack of effective multi-sectoral platform, the influence of food industry, lack of clarity on policy content, culture and organizational culture and changes in policy priorities. Supporting factors for implementing the implementation are: the policy is appropriate to the context of the implementer, individual support from government officials, good financial management mechanism, adequate inter-organizational network, and personal motivation to implement the policy. The efforts to realize the expected food pattern score ing Kutai Kartanegara Regency face obstacles, namely lack of resources both human and financial resources. Supporting factors are support of central government, provincial government and community.

A study about impelementation of School Based Management Policy, show that school effectiveness is related to the quality of administrator, in this case the headmaster. More effective the headmaster plays his role, more effective the school's vision and mission are implemented. Thus, administrator have a major impact on the effectiveness of a policy (Vally G and Daud 2015). The implementation of policy to achieve the expected food pattern score in Kutai Kartanegara Regency is also inseparable from the role of the implementers/actors involved in it, namely the official of the Food Security and counseling Agency and the community. They work together and support each other; thus, the policy can be implemented effectively.

A research conducted by Sriartha and Windia (2015) found that the policy implementation to control the using of rice fields, by local government not effective yet. It was caused by: a) the existing regulation still has weakness, for example, the Regency Spatial Planning has not been translated into more detailed regulation (zoning regulation), does not involve lower classes, lacks of socialization and is less consistent. Meanwhile, there are some rules have expired. b) the community has a negative assessment to the policy implementation of control using rice field carried out by local government. These findings are different from the policy implementation for achieving the expected food pattern score in Kutai Kartanegara Regency. As seen above, the existing policy is appropriate to the problems faced and made by the competent institution. The public and mass media assessment/perception on the policy is good.

\section{Conclusion}

Based on result and analysis conducted, it can be concluded that the policy implementation of achievement the expected food pattern score in Kutai Kartanegara Regency has been effective. The policy implementation has been right policy, right implementers/actors, right target, right target, and right process. 


\section{References}

Chocran, C.L dan Malone, E.F. 1995. Public Policy: Perspective and Choices. New York: McGrawHill inc.

Dwidjowijoto, R.N. 2006. Kebijakan Publik untuk Negara-Negara Berkembang: Model-Model Perumusan, Implementasi dan Evaluasi. Jakarta: Elex Media Komputindo.

Elizabeth, R. 2011. Strategi Pencapaian Diversifikasi dan Kemandirian Pangan: Antara Harapan dan Kenyataan. Iptek Tanaman Pangan, Vol.6, No.2: 230-242.

Mahmudi. 2015. Manajemen Kinerja Sektor Publik. Yogyakarta: Sekolah Tinggi Ilmu Manajemen YKPN.

Miles, M.B, Huberman, A. M, and Saldana, J. 2014. Qualitative Data Analysis: A Methods Sourcebook. Third Edition. USA. California: SAGE Publications.

Minister of Agriculture Regulation No.65 of 2010 concerning Minimum Service Standards of Food Security in Provincial and Regency/City.

Nugroho, R. 2014. Public Policy: Teori, Manajemen, Dinamika, Analisis, Konvergensi dan Kimia Kebijakan. Jakarta: Elex Media Komputindo

Phulkerda, S., Sacks, G., Vandevijvere, S., Worsley, A., Lawrence, M. 2017. Barriers and potential facilitators to the implementation of government policies on front-of-pack food labeling and restriction of unhealthy food advertising in Thailand. Food Policy 71: 101110

Sriartha, I.P. and Windia, W. 2015. Efektivitas Implementasi Kebijakan Pemerintah Daerah dalam Mengendalikan Alih Fungsi Lahan Sawah Subak: Studi Kasus di Kabupaten Badung, Bali. Jurnal Kajian Bali, Vol. 05, No.2, 327-346.

Vally G, S and Daud, K. 2015. The Implementation of School Based Management Policy: an Exploration. Prodia-Social and Behavioral Sciences, 172: 693-700).

Wahab, S.A. 2014. Analisis Kebijakan dari Formulasi ke Penyusunan Model-Model Implementasi Kebijakan Publik. Jakarta: Bumi Aksara. 2008. Analisis Kebijakan: dari Formulasi ke Implementasi Kebijakan Negara. Jakarta: Bumi Aksara. 